\title{
Biomass Equations for Tropical Tree Plantation Species in Young Stands Using Secondary Data from the Philippines
}

\author{
Ma. Regina N. Banaticla ${ }^{1,3,4}$, Renezita F. Sales ${ }^{1}$ and \\ Rodel D. Lasco ${ }^{2,3}$ \\ ${ }^{1}$ College of Forestry, Leyte State University, Visca, Baybay, Leyte, the \\ Philippines \\ ${ }^{2}$ Institute of Renewable Natural Resources, College of Forestry and \\ Natural Resources, UP Los Baños, College, Laguna, the Philippines \\ ${ }^{3}$ World Agroforestry Centre (ICRAF) Philippines, 2/F Administration \\ Building, College of Forestry and Natural Resources, U.P. Los Baños, \\ College, Laguna, the Philippines \\ Laboratory of Landscape Ecology and Planning, Department of Ecosystem \\ Studies, Graduate School of Life and Agricultural Sciences, University of \\ Tokyo, 1-1-1 Yayoi, Bunkyo-ku, Tokyo, Japan
}

\begin{abstract}
Estimation of the magnitude of sinks and sources of carbon requires reliable estimates of the biomass of forests and of individual trees. Equations for predicting tree biomass have been developed using secondary data involving destructive sampling in plantations (mostly less than 10 years of age) in several localities in the Philippines. These equations allow estimates of carbon sequestration to be made at much lower cost than would be incurred if detailed stand inventories were undertaken. The species included in the study reported here include Gmelina arborea Roxb., Paraserianthes falcataria (L.) Nielsen Swietenia macrophylla King and Dipterocarp species in Mindanao, and Leucaena leucocephala de Wit from Laguna, Antique, Cebu, Iloilo, Rizal, and Ilocos Sur. Non-linear regression was used to derive speciesspecific, site-specific and generic equations between yield and diameter of the form $y$ $=\alpha \mathrm{D}^{\beta}$. Equations were evaluated based on the correlation coefficient, standard error of estimate and residual plots. Regressions resulted in high $r$ values $(>0.90)$. In some cases, non-homogeneous variance was encountered. The generic equation improved estimates compared with models used in previous studies.
\end{abstract}

Keywords: Carbon sequestration, non-linear regression, generic equations 


\section{INTRODUCTION}

Climate change is of major community concern, the most recent Intergovernmental Panel on Climate Change (IPCC) assessment report stating with very high confidence that anthropogenic activities since 1750 have lead to a net global warming (IPCC, 2007). The rise in global temperatures has been attributed to emission of greenhouse gases, notably carbon dioxide (Schimel et al. 1995). Forest ecosystems can be sources and sinks of carbon (Watson et al., 2000). Deforestation and change in land use result in a high level of emissions of $\mathrm{CO}_{2}$ and other greenhouse gases. $\mathrm{CO}_{2}$ emissions associated with land-use change were about $1.6 \mathrm{Gt}$ per year over the 1990s (IPCC 2007). Land-use and forestry also have the potential to mitigate carbon emissions through the conservation of existing carbon reservoirs (i.e. by preventing deforestation and forest degradation), improvement of carbon storage in vegetation and soils and wood products, and substitution of biomass for fossil fuels for energy production (Brown et al. 1993). Estimation of the magnitude of these sinks and sources of carbon requires reliable estimates of the biomass of forests and of individual trees.

Direct measurement of tree biomass involves felling an appropriate number of trees and estimating their field and oven-dry weights, a procedure that can be costly and impractical, especially when dealing with numerous species and large sampling areas. Rather than performing destructive sampling all the time in the field, an alternative method is to use regression equations (developed from a previously felled sample of trees) that predict biomass given some easily measurable predictor variable, such as tree diameter or total height. Such equations have been developed for many species (Parde 1980), including fast-growing tropical species (Lim 1988; Fownes and Harrington 1991; Dudley and Fownes 1992; Stewart et al. 1992).

Biomass is typically predicted using either a linear (in the parameter to be estimated) or non-linear regression model, of the following forms:

$$
\begin{array}{lrr}
\begin{array}{l}
\text { Linear: } \\
\text { Nonlinear: }
\end{array} & \mathrm{Y}=\beta \mathrm{X}+\varepsilon & \text { (Equation 1) } \\
\text { where } & \mathrm{Y}=\mathrm{X}^{\beta}+\varepsilon & \\
& \mathrm{Y} & =\text { (Equation 2) } \\
\mathrm{X} & =\text { observed tree biomass } \\
\beta & =\text { model parameter } \\
\varepsilon & =\text { error term }
\end{array}
$$

The nonlinear model can be subdivided into two types: 'intrinsically linear' and 'intrinsically non-linear'. A model that is intrinsically linear can be expressed by transformation of the variables into standard linear form. If a non-linear model cannot be expressed in this form, then it is intrinsically non-linear. An example of an intrinsically linear model is the power function: 


$$
y=\alpha D^{\beta} \varepsilon
$$

(Equation 3)

where

$$
\begin{aligned}
& \mathrm{y}=\text { tree biomass }(\text { or total height }) \\
& \mathrm{D}=\text { diameter at } 1.30 \mathrm{~m}(\mathrm{dbh}) \\
& \alpha, \beta=\text { model parameters } \\
& \varepsilon=\text { error term }
\end{aligned}
$$

Taking the natural logarithms of both sides of the equation yields the linear form:

$$
\ln \mathrm{y}=\ln \alpha+\beta \ln \mathrm{D}+\ln \varepsilon \quad \text { (Equation 4) }
$$

In this form, the regression model can be fitted to biomass (or height) data using standard least squares linear regression. In earlier attempts to develop biomass equations for trees, logarithmic transformation was traditionally employed as a means of linearising non-linear relationships, mainly because of the difficulty of estimating non-linear relationships without the aid of high-speed computers (Payandeh 1981). However, there are disadvantages in using logarithmic transformations, including the assumption of a multiplicative error term in the model (Baskerville 1972) and difficulties in evaluating usual measures of fit such as $\mathrm{R}^{2}$ and the standard error of estimate (SEE) in terms of the original data. In the case of biomass equations, nonlinear models usually produce a better fit than both the logarithmic and multiple linear regression models (Payandeh, 1981).

Many applications of mathematical models for biomass reveal the superiority of the power function (Equation 3 above), notably for estimation of the biomass of stems and roots of trees (Parde 1980; Fownes and Harrington 1991; Ketterings et al. 2000). This model also expresses the long-recognised allometry between stem biomass and girth (Parde 1980).

A generic equation for predicting individual aboveground tree biomass using dbh as predictor variable was developed by Brown (1997) based on data on 170 trees of many species harvested from the moist forest zone of three tropical regions. This equation has been used in previous studies to determine indirectly the biomass and carbon storage of forest ecosystems in the Philippines (Lasco et al. 2002a and b; Lasco et al. 2004) because of the scarcity of local species- or site-specific biomass equations. However, generic equations applied to local data tend to overestimate the actual biomass of trees (Ketterings et al. 2000; Van Noordwijk et al. 2002; Macandog and Delgado 2002), which highlights the need to develop species-specific and sitespecific equations that produce estimates more closely reflecting the characteristics of species and conditions in the Philippines.

\section{RESEARCH METHOD}

For this study, no destructive sampling of trees was done; instead data from two studies involving destructive sampling for biomass determination of trees conducted in several localities in the Philippines by Kawahara et al. (1981) and Tandug (1986) were re-analysed. A general description of the study sites from these sources is provided in Table 1. 
The data sets consisted of individual tree measurements for dbh, total height and total aboveground biomass of tropical tree species, the majority of which are fastgrowing plantation species and were sampled from young stands (mostly less than 10 years old) (Tables 2 and 3). Tandug (1986) developed biomass regression equations with dbh and height as predictor variables. Nevertheless, her data set was analysed in order to develop simpler equations (i.e. those with fewer parameters and which would not require prior transformation of data).

Table 1. Description of sampling sites from which data were sourced

\begin{tabular}{|c|c|c|c|c|c|c|}
\hline Locality & $\begin{array}{l}\text { Climate } \\
\text { type }\end{array}$ & Species & Forest type & Age (yr) & $\begin{array}{c}\text { Stand } \\
\text { density } \\
\text { (stems/ha) }\end{array}$ & Source \\
\hline \multirow[t]{4}{*}{$\begin{array}{l}\text { Aras-asan, } \\
\text { Mindanao }\end{array}$} & IV & $\begin{array}{l}\text { Paraserianthes } \\
\text { falcataria(L.) } \\
\text { Nielsen }\end{array}$ & $\begin{array}{l}\text { Plantation } \\
\text { (timber) }\end{array}$ & $\begin{array}{r}4.9 \\
8.3\end{array}$ & $\begin{array}{r}1085 \\
315\end{array}$ & $\begin{array}{l}\text { Kawahara } \\
\text { et al. } 1981\end{array}$ \\
\hline & & $\begin{array}{l}\text { Swietenia } \\
\text { macrophylla King }\end{array}$ & $\begin{array}{l}\text { Plantation } \\
\text { (timber) }\end{array}$ & 15.3 & 1147 & \\
\hline & & $\begin{array}{l}\text { Gmelina arborea } \\
\text { Roxb. }\end{array}$ & $\begin{array}{l}\text { Plantation } \\
\text { (timber) }\end{array}$ & 9.3 & 1191 & \\
\hline & & Dipterocarpaceae & $\begin{array}{l}\text { Natural } \\
\text { forest }\end{array}$ & Unknown & 1144 & \\
\hline Laguna & I & $\begin{array}{l}\text { Leucaena } \\
\text { leucocephala de Wit }\end{array}$ & Plantation & 9 & 459 & $\begin{array}{c}\text { Tandug } \\
1986\end{array}$ \\
\hline Antique & III & L. leucocephala & Plantation & 4 & 10742 & \\
\hline Cebu & III & L. leucocephala & Plantation & 10 & 1500 & \\
\hline Ilocos Sur & I & L. leucocephala & Plantation & 7 & 8140 & \\
\hline Iloilo & IV & L. leucocephala & Plantation & 5 & 648 & \\
\hline Rizal & I & L. leucocephala & Plantation & $2-4$ & 8926 & \\
\hline
\end{tabular}

Preliminary screening was carried out for each data set, by producing scatter plots of raw (i.e. untransformed) data and log-transformed values of biomass vs dbh (Figures 1 to 4). Plots of log-transformed biomass vs dbh are expected to assume the shape of a straight line, based on the allometric relationship. 
Table 2. Summary data of trees sampled by Kawahara et al. (1981)

\begin{tabular}{lcccc}
\hline Species & $\begin{array}{c}\text { Number } \\
\text { of trees }\end{array}$ & $\begin{array}{c}\text { Dbh } \\
(\mathrm{cm})\end{array}$ & $\begin{array}{c}\text { Total height } \\
(\mathrm{m})\end{array}$ & $\begin{array}{c}\text { Total above- } \\
\text { ground biomass } \\
(\mathrm{kg} / \text { tree })\end{array}$ \\
\hline Paraserianthes falcataria (5-yr old) & 7 & $5.4-20.5$ & $9.3-18.3$ & $3-105$ \\
Paraserianthes falcataria (8-yr old) & 13 & $4.1-36.1$ & $4.3-33.6$ & $3-533$ \\
Gmelina arborea & 7 & $8.0-31.4$ & $7.3-25.0$ & $9-306$ \\
Swietenia macrophylla & 5 & $6.7-26.0$ & $5.6-18.9$ & $7-315$ \\
Dipterocarpaceae & 7 & $7.3-34.0$ & $7.9-26.9$ & $7-473$ \\
\hline
\end{tabular}

Table 3. Summary data of L. leucocephala trees sampled by Tandug (1986)

\begin{tabular}{lcrcc}
\hline Locality or province & $\begin{array}{c}\text { Number of } \\
\text { trees }\end{array}$ & \multicolumn{1}{c}{$\begin{array}{c}\text { Dbh } \\
(\mathrm{cm})\end{array}$} & $\begin{array}{c}\text { Total height } \\
(\mathrm{m})\end{array}$ & $\begin{array}{c}\text { Total aboveground } \\
\text { biomass }(\mathrm{kg} / \text { tree })\end{array}$ \\
\hline Laguna & 18 & $5.4-21.0$ & $5.7-10.5$ & $5-151$ \\
Antique & 13 & $4.5-14.1$ & $9.0-12.7$ & $7-73$ \\
Cebu & 21 & $10.0-31.8$ & $12.3-19.0$ & $36-535$ \\
Ilocos Sur & 18 & $5.2-20.8$ & $10.1-21.0$ & $11-287$ \\
Iloilo & 14 & $5.1-13.8$ & $8.3-10.3$ & $9-76$ \\
Rizal & 27 & $4.0-16.2$ & $5.5-16.1$ & $3-101$ \\
\hline
\end{tabular}

After this initial screening, non-linear regression analysis of the data was performed with CurveExpert v.1.3 (Hyams 1997) software using the LevenbergMarquardt algorithm. Practical experience in the field has shown the difficulty of obtaining accurate measurements of the height of standing trees, especially in natural forest stands. Bearing this in mind, priority has been given to a model with only diameter as predictor variable (Equation 3). Estimates of the parameters $\alpha$ and $\beta$ have been derived for each species and each site in the data sets. Pooled biomass data were also analysed to obtain generic equations with potential wider applicability. In the analysis, the effect of species and site differences on biomass was not considered. Species-specific, site-specific as well as generic equations have been evaluated based on the correlation coefficient (r), standard error of the estimate (SEE) and residual plots. 


\section{RESULTS AND DISCUSSION}

For both data sets, scatter plots of log-transformed value of biomass versus dbh for each species and site (Figures 1 and 2) indicate a good fit to the hypothesised functional relationship.

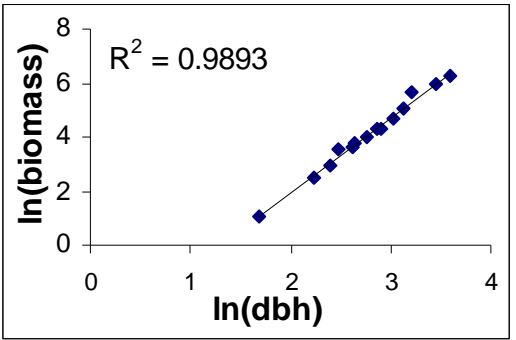

a. $\ln$ (biomass) vs $\ln (\mathrm{dbh}):$ P. falcataria

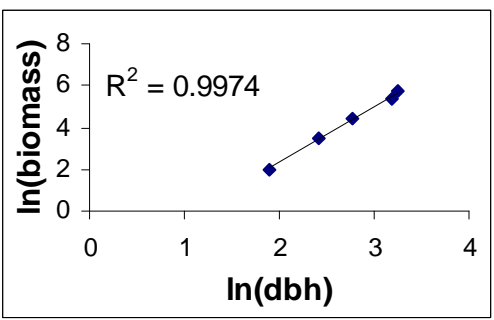

c. $\ln$ (biomass) vs $\ln (\mathrm{dbh}):$ S. macrophylla

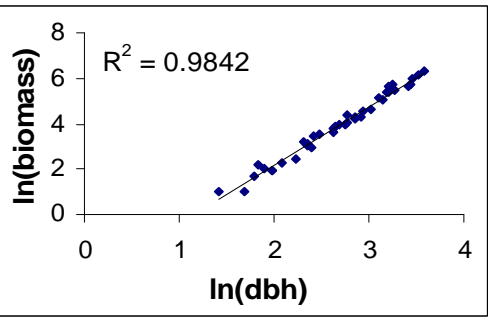

e. $\ln$ (biomass) vs $\ln (\mathrm{dbh})$ : all species

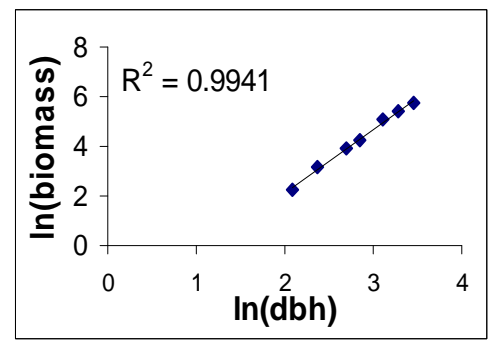

b. $\ln$ (biomass) vs $\ln (\mathrm{dbh})$ : G. arborea

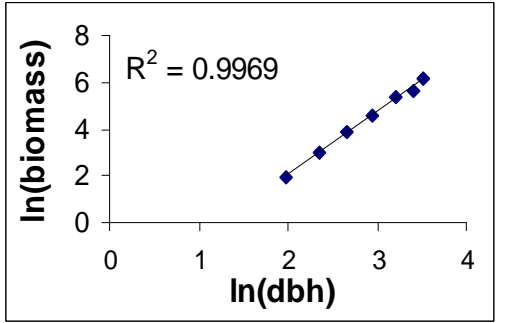

d. $\ln$ (biomass) vs $\ln (\mathrm{dbh})$ : Dipterocarp species

Figure 1. Scatter plots of log-transformed biomass vs dbh from Kawahara et al. (1981) 


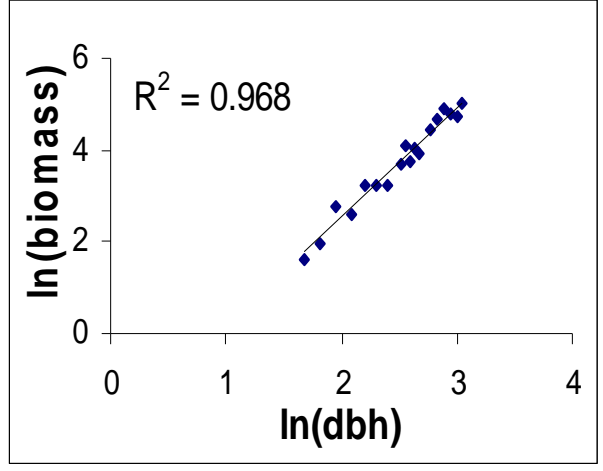

a. $\ln ($ biomass $)$ vs $\ln (\mathrm{dbh}):$ L. leucocephala Laguna

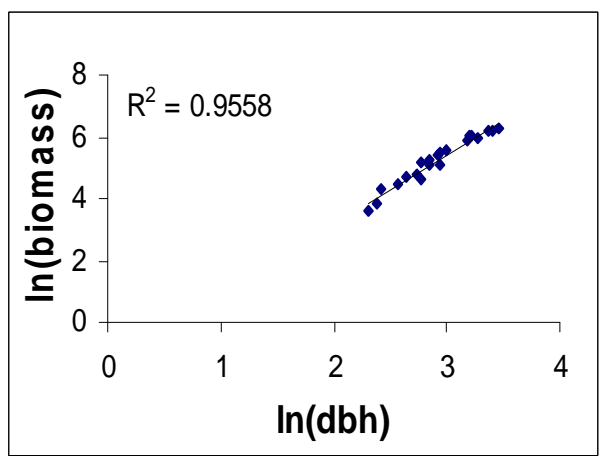

c. $\ln$ (biomass) vs $\ln (\mathrm{dbh}):$ L. leucocephala Cebu

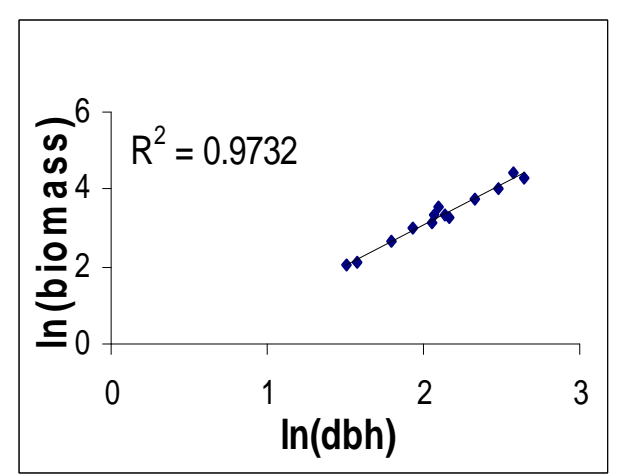

b. $\ln$ (biomass) vs. $\ln (\mathrm{dbh})$ : L leucocephala - Antique

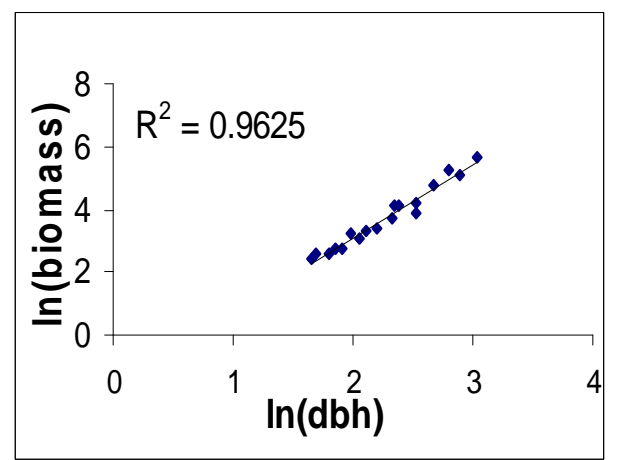

d. $\ln$ (biomass) vs $\ln (\mathrm{dbh}):$ L. leucocephala Ilocos Sur

Figure 2. Scatter plots of log-transformed- biomass vs dbh from Tandug (1986) 


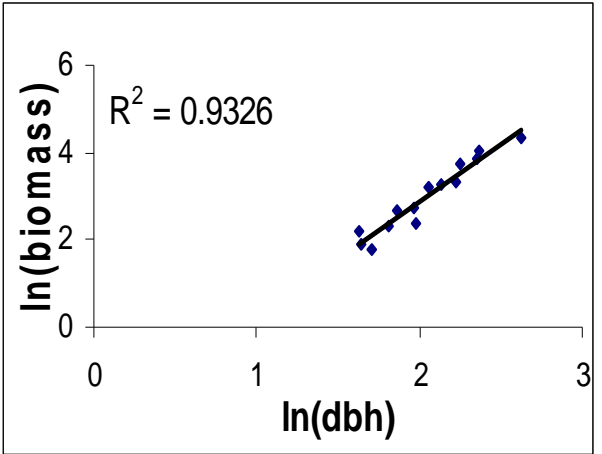

e. $\ln$ (biomass) vs $\ln (\mathrm{dbh}):$ L. leucocephala Iloilo

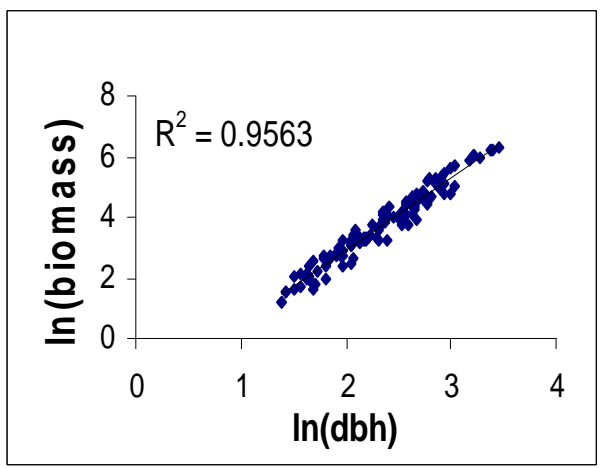

g. $\ln ($ biomass $)$ vs $\ln (\mathrm{dbh})$ : all sites

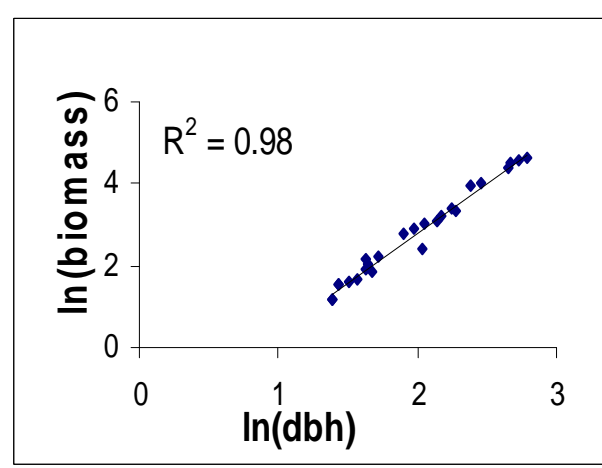

f. $\ln$ (biomass) vs $\ln (\mathrm{dbh}):$ L. leucocephala Rizal

Figure 2. (Cont.) Scatter plots of log-transformed- biomass vs dbh from Tandug (1986)

Estimates for the parameters of the power function fitted to individual species and sites and the pooled biomass data are reported in Table 4, and graphs of the observed vs. fitted values are presented in Figures 3 to 6 . All analyses resulted in high $r$ values $(>0.90)$, although the SEE are highly variable. Figures 3 and 4 show the good fit of the generated power functions for each species-site combination. Figure 4 in particular indicates that in the absence of height data for L. leucocephala, the new equations can adequately approximate the observed biomass values with diameter at breast height as sole predictor variable. The regressions for pooled sites for L. leucocephala (Figure 5) and pooled species and sites - i.e. the Tandug's and Kawahara et al. data combined (Figure 6) - indicate a good fit to the lower range of the data, but greater uncertainty in predicting biomass with greater diameters $(>20 \mathrm{~cm})$. Despite this, as seen in Figure 7, 
the use of the power function $\mathrm{y}=0.342 \mathrm{D}^{2.073}$, improved estimates compared with applying the generic equation by Brown (1997) used in previous studies.

Examination of residual plots (Figures 8 to 10) revealed that in some cases ( $L$. leucocephala in Laguna and Ilocos Sur, and the generic equations), non-homogeneous error variance was present, i.e. the variance increases as dbh increases. Future work should address this problem to improve the predictive ability of the equations. One remedy discussed in Ballard et al. (1998) is the application of a weighting scheme for the non-linear fitting.

Table 4. Summary of regression parameter estimates and statistics for biomass equations for five species using the model $\mathrm{y}=\alpha \mathrm{D}^{\beta}$

\begin{tabular}{lccccccc}
\hline Species & $\mathrm{n}$ & Min D & Max D & $\alpha$ & $\beta$ & SEE & $\mathrm{R}$ \\
\hline Paraserianthes & 20 & 4.1 & 36.1 & 0.049 & 2.591 & 19.766 & 0.991 \\
falcataria & 7 & 8.0 & 31.4 & 0.153 & 2.217 & 13.831 & 0.994 \\
$\begin{array}{l}\text { Gmelina arborea } \\
\text { Swietenia }\end{array}$ & 5 & 6.7 & 26.0 & 0.022 & 2.920 & 17.616 & 0.993 \\
macrophylla & 7 & 7.3 & 34.0 & 0.031 & 2.717 & 24.374 & 0.992 \\
$\begin{array}{l}\text { Dipterocarpaceae } \\
\text { Leucaena }\end{array}$ & & & & & & & \\
leucocephala & & & & & & & \\
$\quad$ Laguna & 18 & 5.4 & 21.0 & 0.132 & 2.316 & 11.424 & 0.972 \\
$\quad$ Antique & 13 & 4.5 & 14.0 & 0.477 & 1.937 & 5.412 & 0.975 \\
$\quad \begin{array}{l}\text { Cebu } \\
\text { Ilocos Sur }\end{array}$ & 21 & 10 & 31.8 & 0.753 & 1.921 & 32.151 & 0.981 \\
$\quad$ Iloilo & 18 & 5.2 & 20.8 & 0.112 & 2.580 & 14.860 & 0.982 \\
$\quad \begin{array}{l}\text { Rizal } \\
\text { All sites }\end{array}$ & 14 & 5.1 & 13.8 & 0.225 & 2.247 & 5.710 & 0.967 \\
$\quad$ combined & 111 & 4.0 & 31.8 & 0.206 & 2.305 & 26.468 & 0.973 \\
$\begin{array}{l}\text { All species/ } \\
\text { sites }\end{array}$ & 148 & 4.0 & 36.1 & 0.342 & 2.073 & 41.964 & 0.938 \\
\hline
\end{tabular}




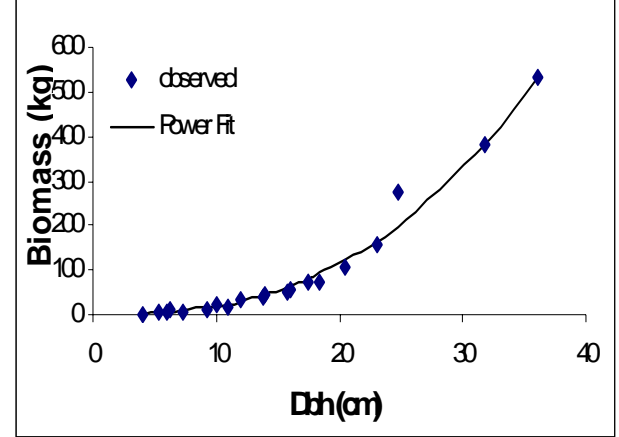

a. P. falcataria

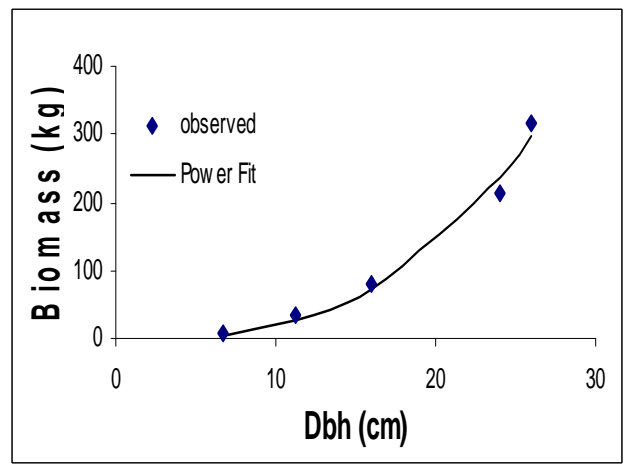

c.S. macrophylla

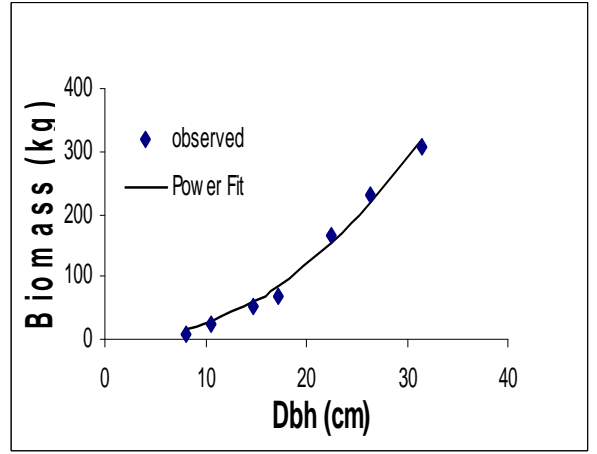

b. G. arborea

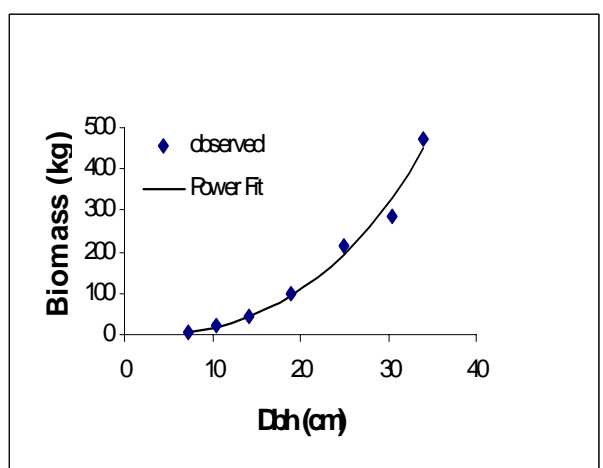

d. Dipterocarp species

Figure 3. Observed vs fitted biomass values for trees sampled by Kawahara et al. (1981).

'Power Fit' refers to allometric equation specific for each species. 


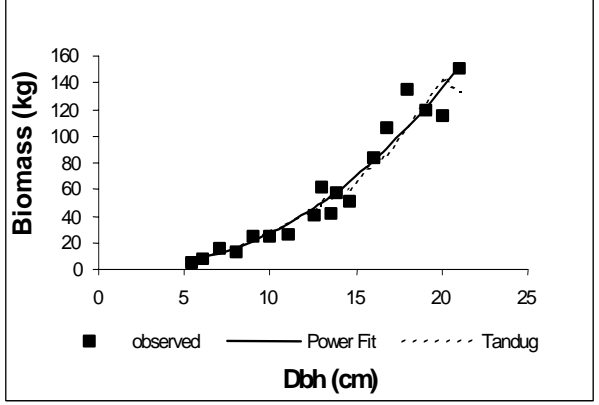

a. L. leucocephala - Laguna

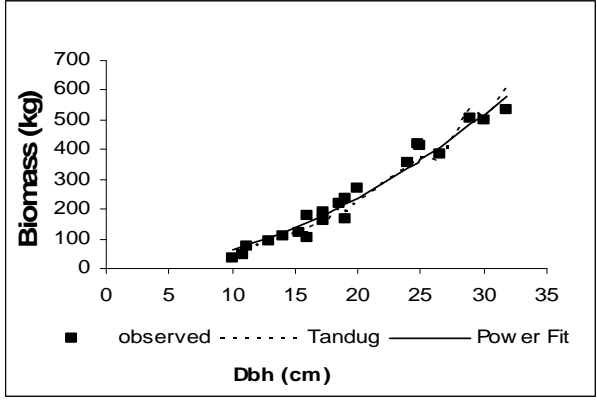

c. L. leucocephala - Cebu

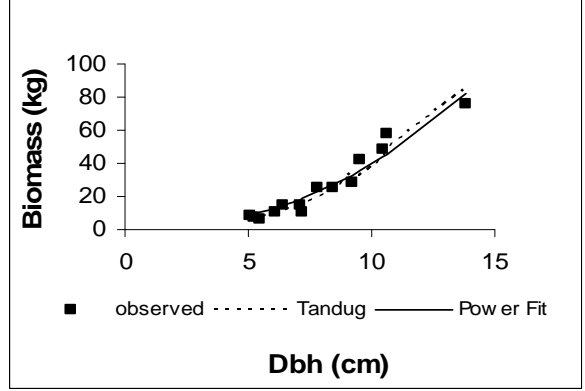

e. L. leucocephala - Iloilo

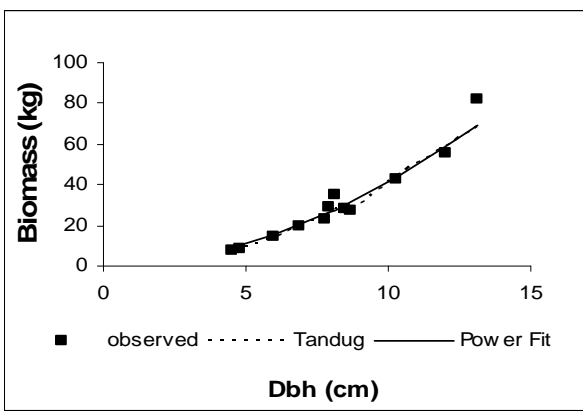

b. L. leucocephala - Antique

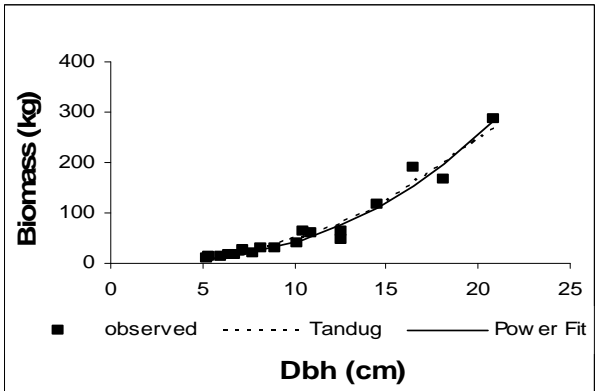

d. L. leucocephala - Ilocos Sur

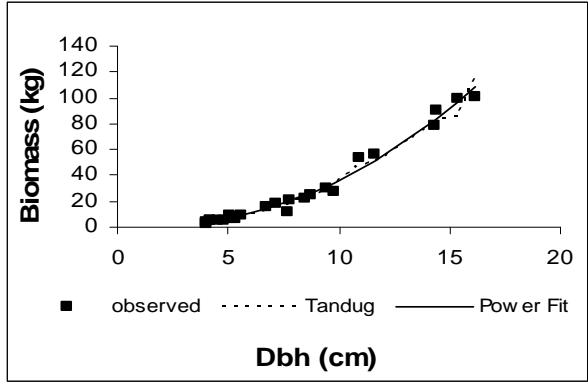

f. L. leucocephala - Rizal

Figure 4. Observed- vs predicted biomass values of trees sampled by Tandug (1986)

'Power Fit' refers to allometric equation specific to a site and 'Tandug' refers to biomass equations by Tandug with dbh and height as predictors $\left(\mathrm{Y}=\mathrm{aD}^{\mathrm{b} 1} \mathrm{H}^{\mathrm{b} 2}\right)$. 


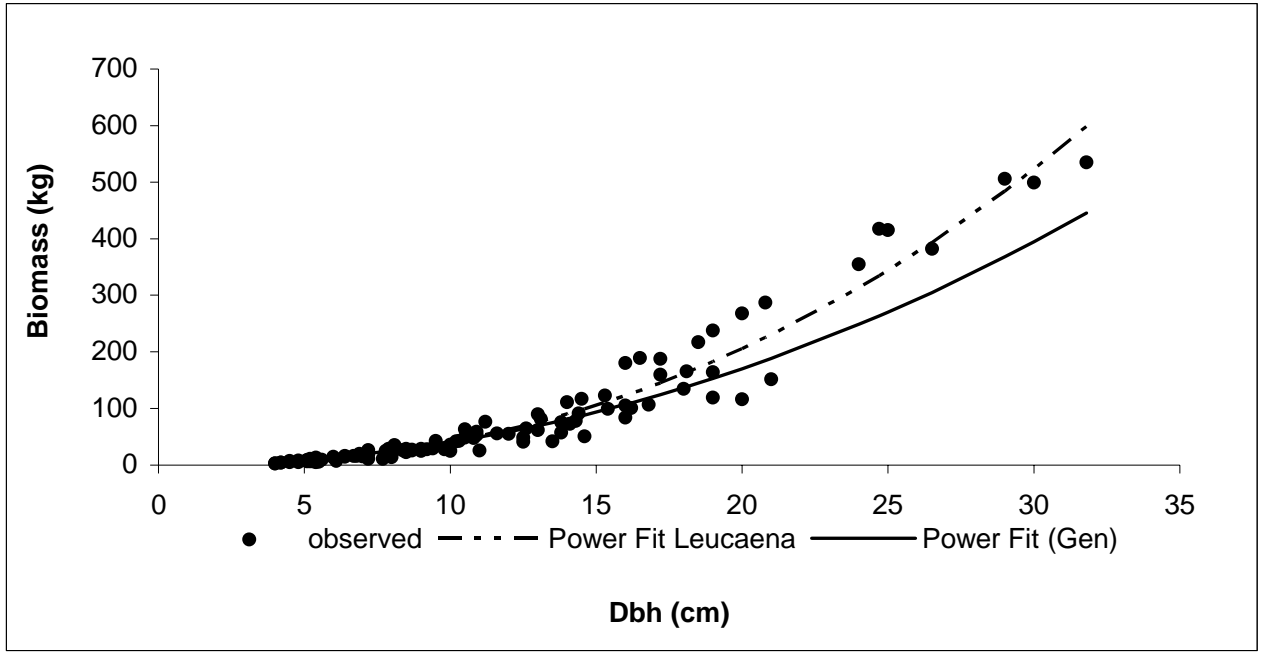

Figure 5. Observed vs predicted biomass values of trees sampled by Tandug (1986)

Individual biomass of trees from the Tandug data set are estimated using the power function $\mathrm{y}=0.206 \mathrm{D}^{2.305}$ fitted to the pooled L. leucocephala data ('Power Fit Leucaena'), and the generic equation $\mathrm{y}=0.342 \mathrm{D}^{2.073}$ fitted to the pooled Tandug-Kawahara et al. data ('Power Fit-Gen').

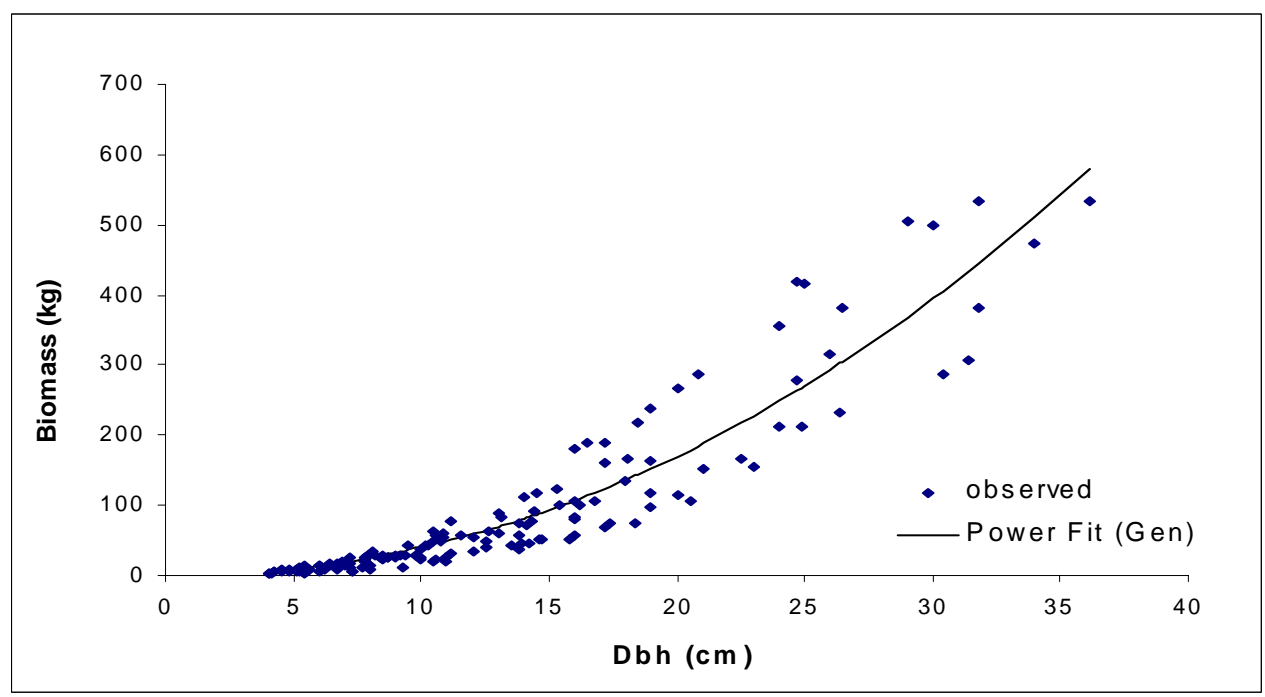

Figure 6. Observed vs predicted biomass values of the pooled Tandug-Kawahara et al. data ( 'Power Fit-Gen' refers to the generic equation $\mathrm{y}=0.342 \mathrm{D}^{2.073}$ ) 


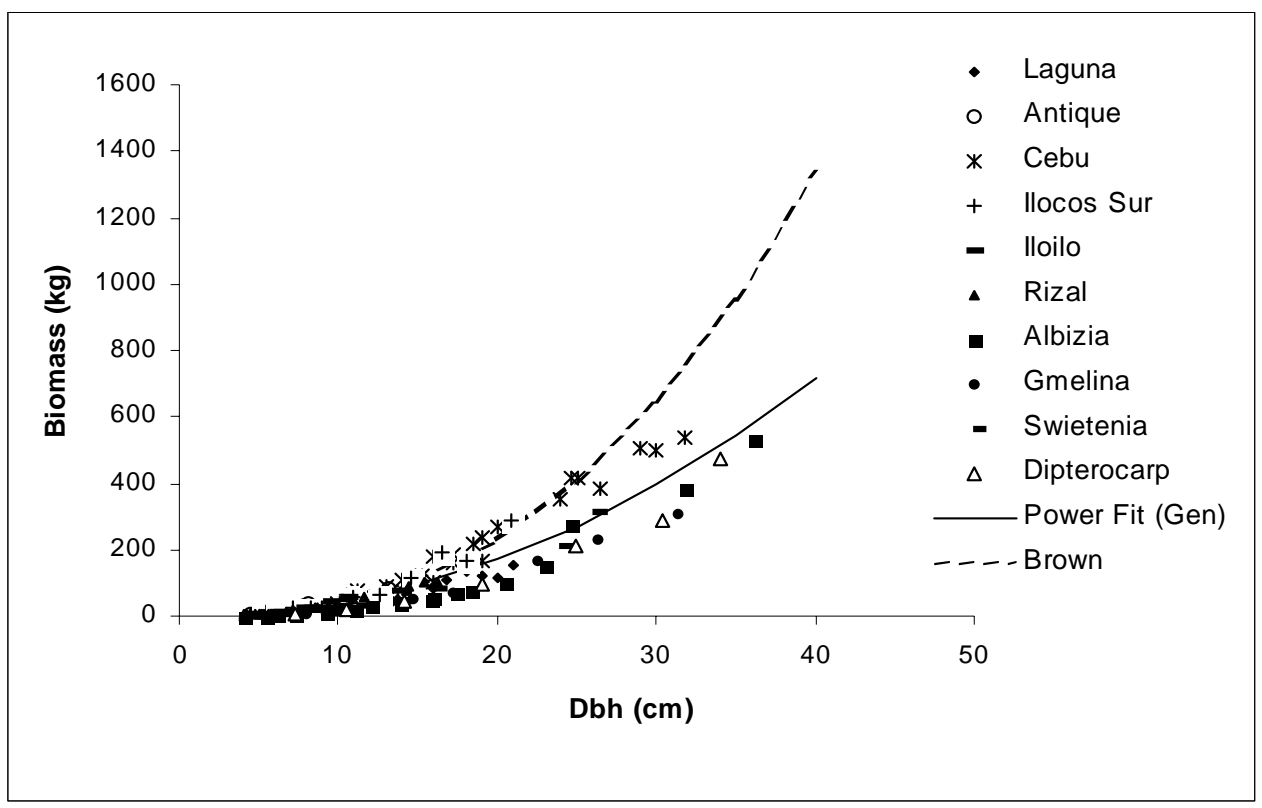

Figure 7. Observed vs predicted biomass values of all trees from the data sets using the generic equation $y=0.342 D^{2.073}$ ('Power Fit-Gen'), and Brown's (1997) equation y $=\exp (-2.134+2.530 \ln (\mathrm{D}))$ 


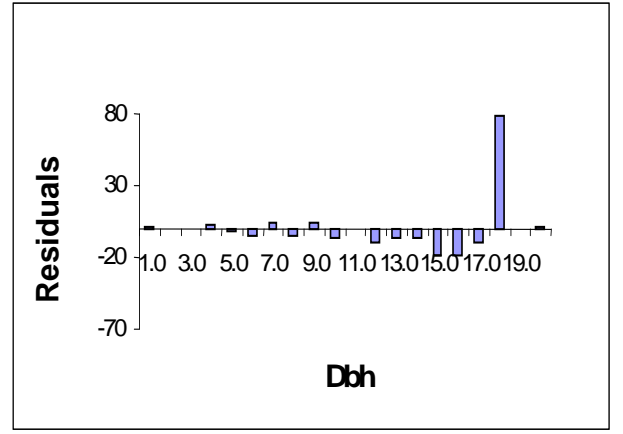

a. P. falcataria

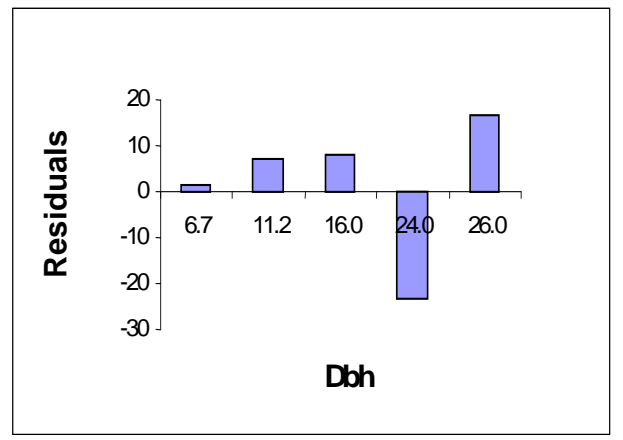

c. S. macrophylla

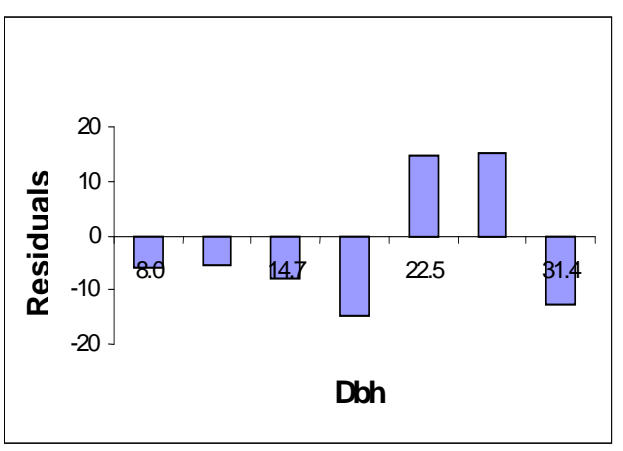

b. G. arborea

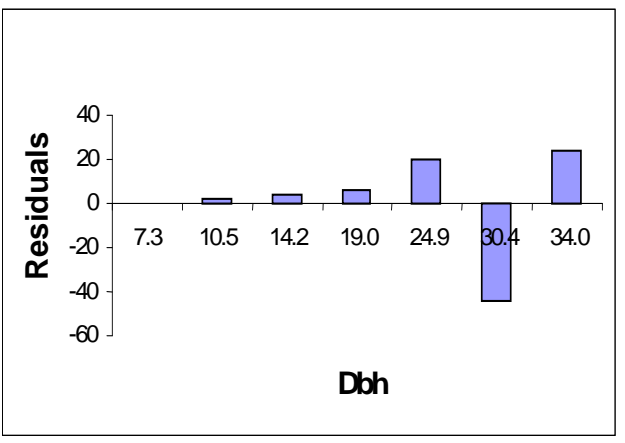

d. Dipterocarps

Figure 8. Residuals from the regressions for species-specific equations from Kawahara et al. (1981) data 

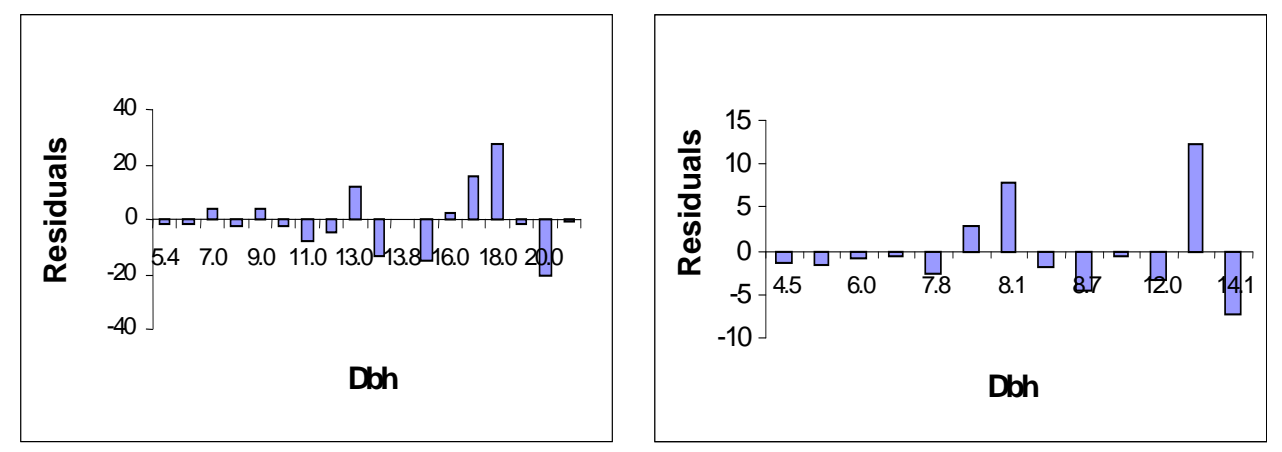

a. L. leucocephala - Laguna

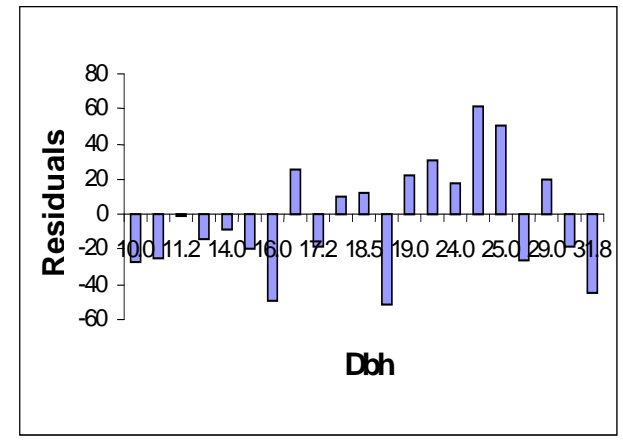

b. L. leucocephala - Antique

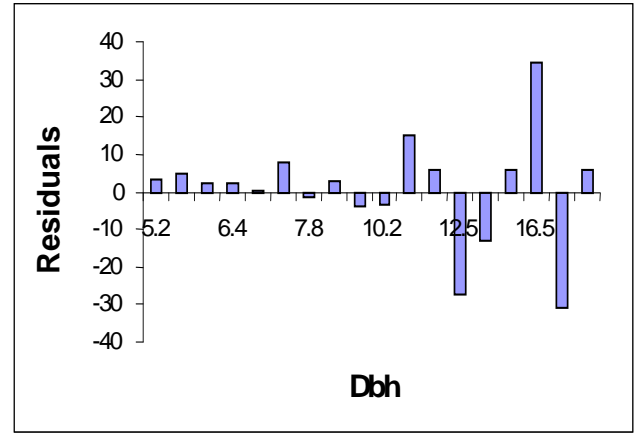

c. L. leucocephala - Cebu

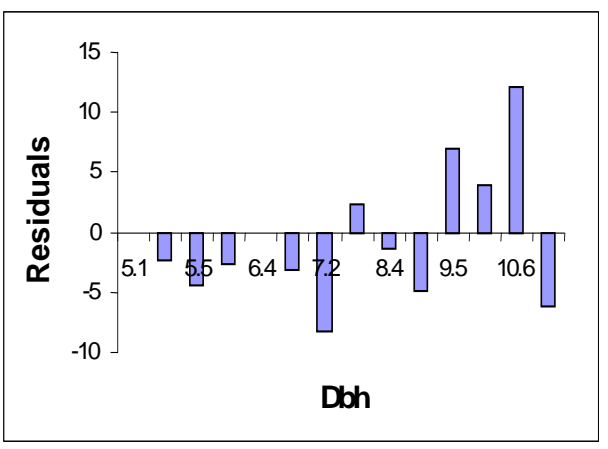

e. L. leucocephala - Iloilo

d. L. leucocephala - Ilocos Sur

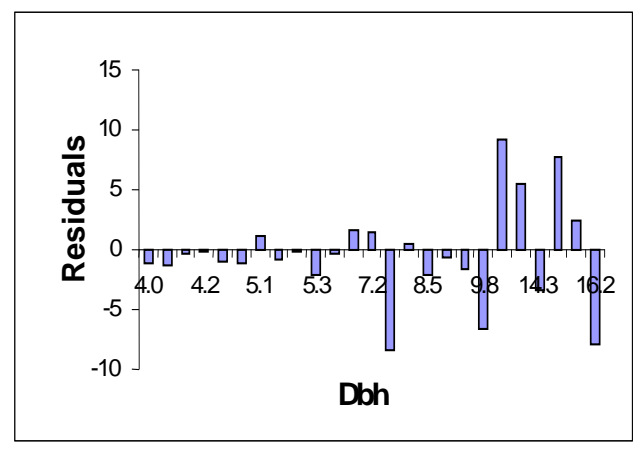

f. L. leucocephala - Rizal

Figure 9. Residuals from the regressions for site-specific equations for $L$. leucocephala from Tandug's (1986) data 


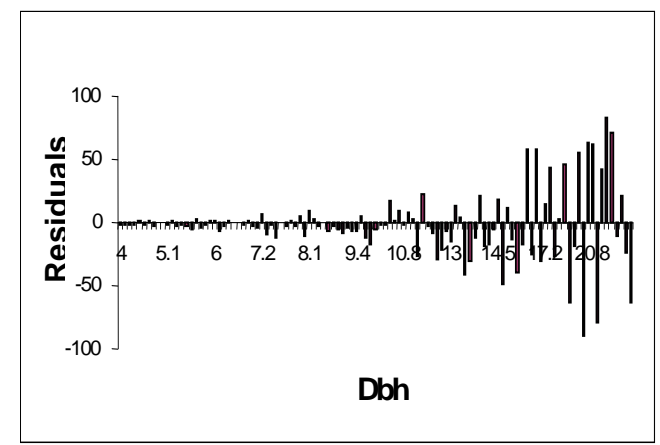

a. Pooled sites - Tandug (1986) data set

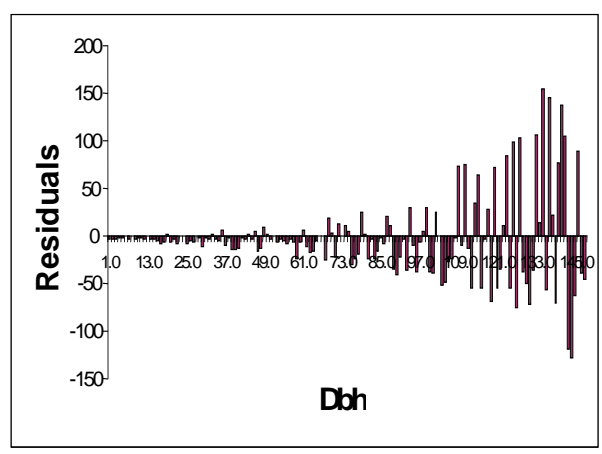

b. Pooled Kawahara et al. (1981) and Tandug (1986) data sets

Figure 10. Residuals from the regressions for generic equations from the pooled Kawahara et al. (1981) and Tandug (1986) data

\section{SUMMARY AND CONCLUSIONS}

Allometric equations for predicting tree biomass were developed using secondary data from Philippine studies involving destructive sampling. Biomass data were taken from studies conducted independently by Kawahara et al. (1981) for timber plantations of Gmelina arborea, Paraserianthes falcataria, Swietenia macrophylla and Dipterocarp species in Mindanao and by Tandug (1986) for Leucaena leucocephala plantations (mainly for dendrothermal power plants) from Laguna, Antique, Cebu, Iloilo, Rizal, and Ilocos Sur. Non-linear estimation was used to fit the data to the power function $Y=\alpha D^{\beta}$, with $Y=$ total above-ground biomass of tree, $D$ $=$ diameter at breast height, and $\alpha, \beta=$ parameters.

Regression equations based solely on diameter appear to estimate adequately tree biomass, with a correlation coefficient of more than 0.90 , although the inclusion of height as predictor variable was not explored. A problem encountered with the regressions is that, in some cases tested, errors in prediction increase with increasing diameter (non-homogeneous variance).

It is emphasised that the biomass regression equations reported here are deterministic in nature, i.e. parameter estimates are single fixed numbers at any given time and applying them on trees under different growing conditions and to age and diameters outside the range of the measurements of the sampled trees is not advised.

Future efforts in equation development should consider including large trees whenever possible, because the analysis reported here shows greater variability in tree biomass among groups at larger diameters $(\geq 30 \mathrm{~cm}$ dbh). The variability in biomass of the various species-sites in the pooled data precludes the development of a 
generalised biomass equation of potential wider applicability. It is still recommended that species- and site-specific equations be used whenever possible.

\section{ACKNOWLEDGMENT}

The authors wish to thank Dr L.V. Tandug of the Ecosystems Research and Development Bureau, College, Laguna, for allowing the use of her data for analysis.

\section{REFERENCES}

BALLARD, B.D., STEHMAN, S.V., BRIGGS, R.D., VOLK, T.A., ABRAHAMSON, L.P. and E.H. WHITE. 1998. Aboveground Biomass Equation Development for Five Salix Clones and One Populus Clone. Biomass for Rural Development Program Interim Status Report No.1. Submitted to the Niagara Mohawk Power Corporation. State University of New York, Syracuse.

BASKERVILLE, G.L. 1972. Use of logarithmic regression in the estimation of plant biomass. Canadian Journal of Forest Research. 2(1): 49-53.

BROWN, S. 1997. Estimating Biomass and Biomass Change of Tropical Forests: A Primer. FAO Forestry Paper 134, Food and Agriculture Organization of the United Nations, Rome.

BROWN, S., HALL, C.A.S., KNABE, W., RAICH, J., TREXLER, M.C. and P. WOOMER. 1993. Tropical forests: their past, present and potential future role in the terrestrial carbon budget. Water, Air, and Soil Pollution. 70(1): 71-94.

DUDLEY, N.S. and J.H. FOWNES. 1991. Preliminary biomass equations for eight species of fast-growing tropical trees. Journal of Tropical Forest Science. 5(1): 68-73.

FOWNES, J.H. and R.A. HARRINGTON. 1991. Allometry of woody biomass and leaf area in five tropical multipurpose trees. Journal of Tropical Forest Science. 4(4): 317-330.

HYAMS, D. 1997. CurveExpert. A curve fitting system for Windows. Version 1.34. http://curveexpert.webhop.biz/. Accessed 25 April 2005.

IPCC (INTERGOVERNMENTAL PANEL ON CLIMATE CHANGE) 2007. Climate Change 2007: The Physical Science Basis. Contribution of Working Group I to the Fourth Assessment Report of the Intergovernmental Panel on Climate Change (Solomon, S., Qin, D., Manning, M., Chen, Z., Marquis, M., Averyt, K.B., Tignor, M. and H.L. Miller eds). Cambridge University Press, Cambridge, and New York.

KAWAHARA, T., KANAZAWA, Y. and S. SAKURAI. 1981. Biomass and net production of man-made forests in the Philippines. Journal of the Japanese Forestry Society. 63(9): 320-327.

KETTERINGS, Q.M., COE, R. VAN NOORDWIJK, M., AMBAGAU, Y. and C.A. PALM. 2000. Reducing uncertainty in the use of allometric biomass equations for predicting above-ground tree biomass in mixed secondary forests. Forest Ecology and Management. 146:199-209.

LASCO, R.D., LALES, J.S., ARNUEVO, M.T., GUILLERMO, I.Q., DE JESUS, A.C., MEDRANO, R., BAJAR, O.F. and C.V. Mendoza. 2002a. Carbon dioxide $\left(\mathrm{CO}_{2}\right)$ storage and sequestration of land cover in the Leyte geothermal reservation. Renewable Energy. 25: 307-315. 
LASCO, R.D., PULHIN, F.B., SALES, R.F. and I.Q. GUILLERMO. 2002b. Carbon stocks assessment of secondary forest and tree plantations in the Philippines: towards improving GHG inventory. In: Highlights of the Research Project for the Southeast Asian Region- LUCF Sector. (D.M. Macandog, R.D. Lasco, R. Boer and P. Chittachumnonk, eds). , Institut Pertanan, Institute for Global Environmental Studies, National Institute for Environmental Studies, UPLB Foundation Inc, University of the Philippines, Los Baños.

LASCO, R.D., GUILlERMO, I.Q., CRUZ, R.V.O., BANTAYAN, N.C. and F.B. PULHIN. 2004. Carbon stocks assessment of a secondary tropical forest in Mt. Makiling Forest Reserve, Philippines. Journal of Tropical Forest Science. 16(1): $35-45$.

LIM, M.T. 1988. Studies on Acacia mangium in Kemasul forest, Malaysia. I. Biomass and productivity. Journal of Tropical Ecology. 4: 293-302

MAGCALE-MACANDOG, D.B. and M.E.M. Delgado. 2002. Regression equation calibration to estimate aboveground biomass of tropical tree species in the Philippines. In: Proceedings International Symposium on Forest Carbon Sequestration and Monitoring (K. Lin and J. Lin, eds). Forestry Research Institute and Winrock International, November 11-15, 2002. Taipei, Taiwan.

PARDE, J. 1980. Forest Biomass. Forestry Abstracts 41(8): 343-362.

PASICOLAN, P.N., UDO DE HAES, H.A., and P.E. SAJISE. 1997. Farm forestry: an alternative to government-driven reforestation in the Philippines. Forest Ecology and Management. 99: 261-274.

PAYANDEH, B. 1981. Choosing regression models for biomass prediction equations. The Forestry Chronicle. 57(4): 229-232.

SCHIMEL, D., ENTING, I.G., HEIMANN, M., WIGLEY, T.M.L., RAYNEUD, D., ALVES, D. and U. SEIGENTHLER. 1995. $\mathrm{CO}_{2}$ and the carbon cycle. In: Climate Change 1994: Radiative Forcing of Climate Change and an Evaluation of the IPCC IS92 Emission Scenarios. (J.T. Houghton, L.G. Meira Filho, B.A. Calander, E. Haites, N. Harris and K. Maskell, eds). Cambridge University Press, Cambridge. pp. 35-71.

STEWART, J.L., DUNSDON, A.J., HELIN, J.J. and C.E. HUGHES. 1992. Wood Biomass Estimation of Central American Dry Zone Species. Tropical Forestry Paper 26. Oxford Forestry Institute.

TANDUG, L.V. 1986. Biomass Prediction Equation for Giant ipil-ipil (Leucaena leucocephala Lam. De Wit.). M.S. Thesis submitted to College of Forestry, U.P. Los Baños, College, Laguna.

VAN NOORDWIJK, M., RAHAYUL, S., HAIRIAH, K., WULAN, Y.C., FARIDA, A. and B. VERBIST. 2002. Carbon stock assessment for a forest-to-coffee conversion landscape in SumberJaya (Lampung, Indonesia): from allometric equations to land use change analysis. Science in China Series C - Life Sciences. 45: 75-86 (Suppl.).

WATSON, R.T., NOBLE, I.R., BOLIN, B., RAVINDRANATH, N.H., VERARDO, D.J. and D.J. DOKKEN (eds). 2000. Land Use, Land-Use Change and Forestry, IPCC Special Report. Cambridge University Press, Cambridge. 